\title{
Perspectives and Legal Implications of Inclusive Access to the Environment for Children Living with Disabilities in Nigeria Under the Discrimination Against Persons with Disability (Prohibition) Act 2018*
}

\author{
Emenike Olisa Mbanugo Esq \\ LL.M, MCIArb (U.K); Emenike Mbanugo \& Co., \\ Chukwuebuka Exceptional Children Foundation, 14, Oshioke Street, Oreyo, off Igbe Road Igbogbo, Ikorodu, \\ Lagos, Nigeria
}

\begin{abstract}
The enactment of the Discrimination against Persons with Disabilities (Prohibition) Act 2018 (DPDPA) is a watershed in the prolonged narrative on the protection of the rights of persons with disabilities in Nigeria. However, the provisions of the DPDPA, especially dealing with access to the environment or physical structures, fall short of global expectations, standards and international law and instruments. The strength and weaknesses of the Act therefore will be examined to ascertain if it has made adequate provisions for the protection or prohibition from discrimination for persons with disabilities especially children. The provisions of the law should be examined to establish its conformity with the enjoyment of human rights and fundamental freedoms guaranteed by the Universal Declaration of Human Rights, the Convention on the Rights of Persons with Disabilities, the Constitution of the Federal Republic of Nigeria, regional and international instruments to which Nigeria is a signatory and existing national and provincial laws. The focus of this paper is the provision on accessibility of physical structure ${ }^{1}$ which prohibit the violation of the right of persons with disabilities to access public building, public transportation and ancillary matters. It will be examined to see whether these provisions can be said to assure access to the physical structure to children with disabilities on equal basis with other children and the general public and also whether they comply with the provisions of the Convention on the Right of Persons with Disabilities (CRPD) to which Nigeria is a signatory. One key question that agitates this paper is whether this law has established adequate mechanism and sufficient institutional framework that guarantees the application and implementation of this law. The National Building Code is a vital key to the effective implementation of the provisions of the DPDPA dealing with access to the environment and relevant provisions of the Code will be discussed. The object of this paper is to provoke a robust enforcement cum implementation of the law, highlighting areas that will require amendment, review or overhaul to bring it in closer alignment with global best practices, international standards and very importantly, the Convention on the Rights of Persons with Disabilities. This paper will attempt to analyse the legal implications of inclusive access on an equal basis and the feasibility of the provisions of the DPDPA aforesaid in comparison with the CRPD and the institutional infrastructure designed to achieve its basic goals.
\end{abstract}

DOI: $10.7176 / \mathrm{JLPG} / 85-15$

Publication date:May $31^{\text {st }} 2019$

\section{Introduction}

All human beings are born free and equal in dignity and rights. ${ }^{2}$ It is the duty of all units of society - family, community, governments - to ensure that this universal principle is applied and sustained at all levels of relationship and in all affairs relevant to the administration of nation states. Everyone is entitled to all the rights and freedoms set forth in the Universal Declaration of Human Rights (UDHR) without distinction of any kind, such as race, colour, sex, language, religion, political or other opinion, national or social origin, property, birth or other status. ${ }^{3}$ More poignantly, UDHR proclaims that all are equal before the law and are entitled without any discrimination to equal protection of the law, and, accordingly, all are entitled to equal protection against any discrimination in violation of this Declaration and against any incitement to such discrimination. ${ }^{4}$ Barriers to full social and economic inclusion of persons with disabilities include inaccessible physical environments and transportation, the unavailability of assistive devices and technologies, non-adapted means of communication, gaps in service delivery, and discriminatory prejudice and stigma in society. ${ }^{5}$

In 2006, about 650 million people or $10 \%$ of the World population were persons with disabilities and of this

\footnotetext{
${ }^{1}$ Discrimination Against Persons with Disability (Prohibition) Act 2018, Part II

${ }^{2}$ Article 1 Universal Declaration of Human Rights, United Nations 1948.

${ }^{3}$ Op cit Article 2

${ }^{4}$ Op cit Article 7

${ }^{5}$ World Bank Group, Disability Inclusion, accessed online at https://www.worldbank.org/en/topic/disability April $12,2019$.
} 
number, 150 million representing more than $20 \%$ of persons with disability were children. ${ }^{1}$ Though the 2011 World Report on Disability maintains this figure, it may no longer be realistic with recent world events. Presently, there are 1 billion persons with varying forms of disability in the world representing about $15 \%$ of the world population. ${ }^{2}$ Disability in children are usually a product of several factors including circumstances of their birth, war, poverty, disease and accident and are therefore covered by "birth and other status" under Article 2 of UDHR. With many regional and national wars, more children and indeed adult population have joined the disability community with severe demand for inclusive access to the environment. Access to the environment nay physical structure is a vital index for the attainment of the human rights of every citizen because it entails access to all aspects of life and enables the citizen to pursue the attainment of personal fulfilment and contribution to national development. For children with disability, this index is central to their growth pattern, overall life development and inclusion in society without any form of discrimination, ostracism or stigmatisation. The enjoyment of all other rights of access - education, training, health care services, recovery services, preparation for employment and recreation opportunities - are dependent on the non-discrimination and availability of the right to the physical structures which house the facilities that provide these cares.

\section{The Role of the State}

The Federal Government of Nigeria has a crucial role to play to ensure that the country's future generation, the hope of any nation, are provided with sufficient resources to attain personal fulfilment since the ultimate goal is to encourage them to contribute to National Development as viable and prosperous citizens. It is certain that majority of persons with disability in Nigeria today are persons who are living with disability resulting from circumstances of birth and other on-set childhood incidents. The minority who are essentially adults acquired disability from accidents, war and sickness. Thus, it is unarguable that the application of the DPDPA should have children with disability as the epicentre of its implementation activities. This can be achieved by providing the infrastructure to enforce the DPDPA with zest to accommodate emphasis on children with disability and give vent to government's inclusive policy on building, growth and prosperity. ${ }^{3}$ It is gratifying to observe that the resolutions ${ }^{4}$ of the National Council on Lands, Housing and Urban Matters, the body seised with articulating policy for the development of the environment and physical structure in Nigeria, addressed issues related to the subject of inclusion which are of utmost importance to children and other persons living with disabilities. The relevant resolutions are set forth as follows:

"4. Council considered the issues raised in the Memoranda presented at the Meeting and adopted the following resolutions:

xxx. directed that States Building Control Agencies be strengthened so that any building springing up, would be regulated and must be environment friendly,

xxxi. approved that functionality, cultural peculiarities and inclusiveness should guide the location, design and construction of houses in all Governments Housing Programmes;

xxxvi. endorsed the adoption of the 'Rent-to-Own' product by all tiers of Government to improve housing inclusion, growth and economic prosperity"

There is no doubt that ensuring that buildings springing up in urban and rural settings are environmental friendly, expresses inclusion of all categories of persons bordering on functionality and grants access on an equal basis to persons with disabilities especially children will accord with the object of the DPDPA and the Convention on the Rights of Persons with Disabilities. This is a worthy and noble objective which when fully implemented will in no small way ameliorate the trauma and anguish of persons with disability.

\section{The Challenge of Children with Disability}

Current global attention on children with disabilities is focused substantially on inclusion - inclusive education, inclusive access to the environment, inclusive rights, mainstreaming, etc. The singular most repressive challenge of children living with disabilities is stigmatisation, discrimination and exclusion by their families, society, communities and government. The application or implementation of policies, values and norms scarcely have any regard to the interest of children with disabilities who could perhaps be considered the most excluded group on earth. Yet, the law stipulates that in every action concerning a child, without any distinction or discrimination, whether with disability or without disability, the overall interest of the child shall be given paramount

\footnotetext{
${ }^{1}$ United Nations Committee on the Rights of the Child, $43^{\text {rd }}$ Session, General Comment No. 9, The Rights of Children with Disabilities

${ }^{2}$ World Bank Group, Op cit

${ }^{3}$ The theme of the meeting of the National Council on Lands, Housing and Urban Matters held at the NAF Conference Centre, Kado, Federal Capital Territory, Abuja on August 24, 2017, was “Building for Inclusion, Growth and Prosperity". At the meeting, the Honourable Minister for Workers, Power \& Housing, Mr. Babatunde Raji Fashola S.A.N was quoted as having said that his ministry was "finalising designs to accommodate our cultural, climatic and other diversities and when the designs are completed, we will commence construction to pilot the designs and test them for affordability and acceptance".

${ }^{4}$ Paragraphs 4(xxx), 4(xxxi) and 4(xxxvi
} 
consideration. ${ }^{1}$ The enactment of the DPDPA and the current robust approach of the National Council on Lands, Housing and Urban Matters though commendable has not shown a demonstration of the importance of right of access to the environment for children especially children living with disabilities. Interestingly, Lagos State blazed a trail which is yet to be rivalled in enacting the Lagos State Special People's Law and creating the Lagos State Office for Disability Affairs (LASPODA) in 2010. There is therefore justification to inculcate the principles of the DPDPA and LASPODA into the National Council's policy direction and implementation as a way of engaging global best practices for the future of the Nigerian Child, the Sustainable Development Goals and the development of Nigeria.

\section{The Impact of Discrimination and Prohibition}

Discrimination is defined as the effect of a law or established practice that confers privileges on a certain class or that denies privileges to a certain class because of race, sex, nationality, religion or disability. ${ }^{2}$ When viewed from this perspective alone, discrimination as used in the DPDPA will be narrow and restricted to only the conferment and denial of privileges and this approach will therefore be inadequate for a consideration of the full spectrum of the rights of children and other persons living with disability. This is because privilege, as a special legal right, exemption, or immunity granted to a person or class of persons; an exception to a duty ${ }^{3}$ does not meet with the demand for enforcement of human rights on an equal basis with others. Rather, it grants someone the legal freedom to do or not to do a given act and immunises conduct that under ordinary circumstances would subject the actor to liability. ${ }^{4}$ To the world of disability, discrimination is the denial of inclusion in the family, community and society on the basis of disability or in another way, exclusion from society on grounds of disability. Denial of inclusion comes in various ways and includes especially the denial of access to appropriate health care, education, justice and other human rights and fundamental freedoms ordinarily entitled to other members of society without disability.

Discrimination excludes a child from the life of the community in the application of different rules to comparable situations and the application of the same rules to different situations. Children with disability are often treated with bias by policy makers and administrators who apply different rules in situations concerning, for instance, access to a school play ground where there is no provision for ramps or lifts, and to even the same facilities which other children without disability enjoy. On another plane, applying the same rules to different situations deny children with disability the support and assistance which they need and are entitled. Therefore, to attain the general principles of inclusion, mainstreaming, non-discrimination and accessibility for children with disability, the environment should be usable, understandable and practicable for children with disability in safe conditions and in the most autonomous way possible.

Prohibition is defined as a law or Order that forbids a certain action ${ }^{5}$, a command not to do a thing or not to refrain from doing something. Prohibition is usually an appropriate tool to enforce compliance with law at the pain of sanctions or punishment. In prohibiting discrimination against children and other persons with disability, it is crucial that the State views discrimination in the society with some measure of seriousness and a determination to enforce the law. It can be seen from the DPDPA that any failure or neglect to comply with the provisions of the Act relating to access to the physical environment will attract imprisonment or the payment of fines and deserving cases to both fines and imprisonment. This is laudable but what is left to be seen is the deployment of State administrative machinery and institutional mechanism to ensure the implementation of the law. The effort of the United States of America to enforce the national prohibition of alcohol undertaken to reduce crime and corruption, solve social problems, improve health and hygiene and reduce the tax burden created by prisons and poorhouses between 1920 and 1933 was a failure. ${ }^{6}$ Rather than serve the intended purpose, it created an enormous public demand for illegal alcohol and crime increased as notorious gang leaders battled for control of illegal drinking dens.

The DPDPA has awarded a generous transition time line of 5yeras for owners of physical structures - public buildings, parks, gardens, vehicles, and so on to ensure the provision of ramps, lifts and other physical aids that will assist the disability community. For children with disability, this will translate essentially to having these facilities at schools and other places of leisure, transportation and healthcare where they can enjoy their right of access on equal basis with other children. It is contended that the period of transition shall be used by administrators and judicial officers to prepare and provide an adequate framework and mechanism for the enforcement and implementation of the DPDPA. This period should be used to enhance the creation of awareness of the law and promote a mindset of civic responsibility other than the pain of punishment

\footnotetext{
${ }^{1}$ Section 1, Child Rights Act 2003

2 B. Garner: Black's Law Dictionary, 2009,Thomson Reuters, $9^{\text {th }}$ Edition, Page 526

${ }^{3}$ Garner, op cit. Page 1316

${ }^{4}$ Ibid

${ }^{5}$ Op cit, Page 1331

${ }^{6}$ Prohibition: Unintended Consequences, What was bad about Prohibition, www.pbs.org>kenburns accessed at 4.45p.m on 09/04/2019
} 


\section{The Right of Access to Physical Structures under the DPDPA}

The DPDPA guarantees the right of persons with disabilities to access the physical environment and public buildings on an equal basis with others. ${ }^{1}$ In furtherance of this right, the DPDPA stipulates that public buildings shall be constructed with necessary accessibility aids such as lifts (where necessary), ramps and any other facility that shall make them accessible and usable to persons with disability. ${ }^{2}$ It also provides that road-side walk, pedestrian crossing and all other special facilities for public use specified in the First Schedule to the DPDPA shall be made accessible and usable by persons with disabilities including those on wheel chairs and visually impaired. ${ }^{3}$ The law further mandates that existing public buildings and structures, whether immovable, movable or automobile shall be modified within the next five years to ensure that they are accessible to persons with disability within the context of the law. ${ }^{4}$ It specifically provides that governments or their agencies or bodies or individuals charged with granting building approval shall ensure compliance with the provisions of the Building Code on accessibility and makes it a criminal offence punishable with two years imprisonment or fine of N1,000,000.00 for any breach of this requirement. ${ }^{5}$

In dealing with access to transportation, for instance, the DPDPA provides that public transport providers, including government and its agencies, shall ensure accessibility to their vehicles, parks and bus stops by ensuring the availability of lifts, ramps and other accessibility aids for persons with disabilities including those on wheelchairs within five years of the enactment of the DPDPA. ${ }^{6}$ It is also provided that every public vehicle shall have functional audible and visible display of their destinations and shall be maintained in operational condition subject to prompt repair or replacement where they malfunction. Also, the driver of a public vehicle shall ensure that his vehicle has completely pulled up to enable a person with disability to board or alight therefrom and other passengers are mandatorily required to wait until a person or persons with disability have first boarded the vehicle.

As there is no exemption of any kind for the nature of public transport provider required in these provisions, it means that all transportation providers - local, regional, intrastate, interstate and international - must mandatorily meet the above requirements of the law. Most importantly, for children with physical, sight and hearing disabilities especially those on wheel chairs, public transportation must comply with the provision of ramps and functional audible and visual display of destinations. Training and re-training of drivers of public transportation should be enhanced to ensure the observance of the Driving Code and stiffer penalty should be applied for persons or drivers who fail to completely pull up to enable a child with disability to alight or board the vehicle. Indeed, government should increase awareness among the populace to enlighten the citizenry on the need to give priority to children with disability at queues or points of embarkation and disembarkation of public transportation and other physical structures.

It is observed that other significant areas of accessibility addressed by the law include parking lots ${ }^{7}$, seaports and railways ${ }^{8}$ and aircrafts. ${ }^{9}$ Too many times, parking space provided for persons with disability in parking lots are taken up by other persons outside the category while in some cases, the spaces are far from the point of egress into the structure sought to be accessed. Enforcement is therefore the key. Indeed, the transparent enforcement of these provisions by government agencies will, no doubt, express the manifest willingness and determination of government to enforce the DPDPA. It should also act as a check on the abuse of accessibility equipments and aids to public transportation and the violation of the rights of persons living with disability especially children who are more at risk in accessing public environment and vehicles.

However, there is room for improvement in these provisions which hopefully will be addressed by the legislature in due course. For example, access to the seaports, railways and airports should not cease with gaining access to the vessels, aircraft and trains but must extend to gaining access to all other facilities offered on-board on an equal basis with other passengers. Children and other persons with disability should be able to access adaptable restrooms or general restrooms and have sufficient room to accommodate the navigation of their wheelchairs on board vessels, aircraft and trains. The implication is that aircraft manufacturers should provide sufficient space and appropriate platform in aircraft restrooms for children with disability and parents and caregivers who clean up and change diapers of their children.

Although the DPDPA stipulates what are special facilities in the First Schedule, it would appear that the requirement of such facilities is limited to Part II of the DPDPA dealing with the physical environment. Accordingly, the use of wheel chairs on choked, narrow and cramped trains, vessels and aircraft without accessible aisles and spaces, toilet facilities and inadequate wheelchair passage and turning space present an immediate

\footnotetext{
${ }^{6}$ Section 3

${ }^{2}$ Section 4

${ }^{3}$ Section 5

${ }^{4}$ Section 6

${ }^{5}$ Section 7

${ }^{6}$ Section 10

${ }^{7}$ Section 12

${ }^{8}$ Section 13

${ }^{9}$ Section 15
} 
challenge as it deprives the child or other persons with disability of their right of access to the environment on equal basis with other citizens and in some cases, demean their dignity. For instance, a child with disability under severe pressure to relieve himself may find it extremely difficult to navigate through cluttered terrains to access toilet facilities if the corridors and aisles fail to meet the requirements of the National Building Code of the Federal Republic of Nigeria. ${ }^{1}$ It is therefore imperative that the implementation and enforcement of the DPDPA shall take full cognisance of the provisions of the Code.

\section{The National Building Code}

As has been stated above, the DPDPA mandates that before the erection of any building, the appropriate authority must scrutinise the building plan to ensure that it conforms with the building code. ${ }^{2}$ The Code requires that every building or structure whether existing or subsequently erected shall comply with the classification in the Code according to the use or character of its occupancy. ${ }^{3}$ It stipulates that its provisions dealing with environmental and general building requirements, where required, shall apply to all buildings and portions classified under User Groups A, B, C, F, G and $\mathrm{H}$ with minimal exceptions unrelated to the physically challenged and the aged. ${ }^{4}$ Although this provision limits the incidence or spectrum of disability to the physically challenged and the aged, it nevertheless established sufficient standard to plan the environment to accommodate the disability community. User Groups A, B, C, F, G and H represent Assembly Uses, Business and Professional Uses, Education Uses, Institutional Uses, Mercantile Uses and Residential Uses respectively.

The implication of construing the provisions of Part II of the DPDPA dealing with accessibility of physical structure, therefore, is that it is imperative that the provisions of the Code shall be accorded adequate consideration to ascertain if the requirements of existing or emerging physical structures which guarantee access to persons with disability especially children have been complied with. The DPDPA, for instance, did not define public buildings as used in the law but the classification of uses of buildings in the Code easily highlights what buildings can be classified as public buildings. This is boosted by the provisions of the DPDPA which require that before erecting any structure, the "plan shall be scrutinised by the relevant authority to ensure that the plan conforms with the building code" It is an offence for any government, government agency, body or individual to approve a building plan which is not in compliance with the $\mathrm{Code}^{6}$ and such offender is liable to a fine of not less than N1,000,000.00 or a term of imprisonment of two years or to both fine and imprisonment. ${ }^{7}$ It is commendable that the DPDPA has provided for a transitory period of five years within which all existing public buildings and structures, whether automobile, moveable or immoveable, which were inaccessible to persons with disabilities, shall be modified to be accessible by persons with disabilities including those on wheelchair ${ }^{8}$ especially children. Children who are denied their right to access public transportation, educational environment, parks, and public buildings to which other children have access etc. are more at risk to suffer from depression, molestation, violence, loneliness and withdrawal.

\section{User Groups under the National Building Code}

In furtherance of the protection of the right of access to the environment for children with disabilities, it would appear that the relevant user groups of interest to children with disabilities are User Groups A, C, F, G and H. The Code has defined User Group A to include all buildings and structures or parts thereof which are used or designed for the gathering together of persons for purposes such as civic, social or religious functions, recreation, food or drink consumption or awaiting transportation. This classification will include such places as parks and gardens, events halls, stadia, theatres, night clubs, restaurants, eateries, auditorium, churches, mosques, etc. ${ }^{9}$ Instances where persons with disabilities are denied access to eateries because of a total absence or inadequacy of ramps into the place abound while a visit to most of our places of worship today will portray a similar if not worst situation. Thankfully, the DPDPA has provided a five year transitory period for all existing user groups to comply with the law or face the consequences. Similar provision is contained in the Lagos State Special People's Law (LASSPOL) but whether this provision has been enforced in Lagos State more than eight years after the enactment of the law is left to conjecture. Relevant government agencies at all levels must ensure that children with disabilities have access independently or assisted to this user group without clutter, obstacles or hindrance. The proposed National Commission for Disabilities has quite an herculean task considering the enormity of the abuse and violation of the right of access to the environment occasioned on children with disabilities.

\footnotetext{
${ }^{1} 20061^{\text {st }}$ Edition

${ }^{2}$ Section 7

${ }^{3}$ Section 4.2.1

${ }^{4}$ Section 6.3 .8

${ }^{5}$ Section 7(1) DPDPA

${ }^{6}$ Section 7(2)

${ }^{7}$ Section 7(3)

${ }^{8}$ Section 6

${ }^{9}$ National Building Code (2006) Section 4.3
} 
User Group C covers all buildings and structures or any part thereof used by more than five persons at one time for educational purposes through secondary school including schools and academics. ${ }^{1}$ This section of the Code is particularly important to children with disabilities in the drive for inclusive access and inclusive education guaranteed by the DPDPA ${ }^{2}$ as it particularly deals with range of schooling during child life. One of the aims of Special Needs Education is to provide access to education for all persons, in an inclusive setting and securing the provision of all necessary facilities, equipment, materials and other assistive devices that would ensure easy access to quality education for persons with disabilities. ${ }^{3}$ It is submitted that the correlation of access to the environment and access to education is that a denial of access to the venue of inclusive, equal and quality education by noncompliance with the requirements of the building code for educational purposes is a discrimination of the right of children with disabilities to access quality education on an equal basis with other children guaranteed by the Child Rights Act ${ }^{4}$ and the Free, Compulsory and Universal Basic Education Act. ${ }^{5}$ One of the cardinal objectives of education is the holistic development of life, the individual and the nation which inexorably leads to social, economic and political growth.

In the same vein, all buildings and structures or parts thereof, harbouring people suffering from physical limitations because of health or age are classified in User Group F, titled "Institutional Use". ${ }^{6}$ It includes buildings or parts thereof such as social rehabilitation facilities, hospitals, nursing homes, board and day care, and convalescent homes housing six or more individuals who because of age, mental disability or other reasons must live in a supervised environment but who are physically capable of responding to an emergency situation without assistance. ${ }^{7}$ Notably, the Code prescribes for child care facility housing more than five children of 4years or less and emphasises "custodial care on a 24-hour basis of six or more persons who are not capable of self-protection." Institutions for persons with disabilities especially children abound and do not necessarily derogate from inclusion but act as a buffer for extreme cases of disability that cannot ordinarily be accommodated in inclusive environment. There is no gain-saying the fact that these institutions should be a model for access to children with disabilities and effort should therefore be made to ensure that the quality of life, health, education and other opportunities, rights and freedoms available to other children should be assured at such facilities.

Another building classification created by the Code is User Group G designated for "Mercantile Uses" and includes all buildings and structures and parts thereof used for display and sales purposes involving stocks of goods, wares or merchandise incidental to such purposes and accessible to the public. ${ }^{9}$ It includes retails stores, motor fuel service stations, markets, shops and salesrooms, etc. A cursory visit to some shopping malls, plazas, markets and such other places designated or applied for mercantile purposes will readily expose the discrimination meted to children with disabilities who by themselves or with their parents or caregivers can hardly navigate those places in their wheelchairs. Apart from the unavailability of ramps and adequate corridors or aisles, ubiquitous stocks, goods, carts and tables litter and clutter every available space on the aisles and corridors in these places making movement extremely difficult and strenuous if not impossible even for persons without disability. Other mercantile users would be required to display more regard for the peculiar needs of persons with disabilities especially children. In some cases, children with disabilities suffer discrimination in their society because of rejection at local shopping malls where shop attendants and, sometimes, shop owners turn back their wheelchairs from their shops, refuse to assist them gain egress or out-rightly refuse to sell to them.

Perhaps, of utmost interest to children living with disabilities is the classification of "Residential Uses" in User Group $\mathrm{H}$ which includes all buildings and structures or parts thereof where households live or in which sleeping accommodations are provided for individuals with or without dining facilities. It includes hotels, motels, boarding houses, dormitories, multiple family dwellings and similar buildings arranged for shelter and sleeping accommodation and whether for transient or permanent purposes. This user group is of particular interest and concern because of its central role in urban and rural migration which bring households and families into common dwelling environments. It is noticeable that in the absence of government-owned accommodations especially in urban areas, private developers have held sway providing living accommodations for needy dwellers. However, it is generally known that a sizeable number of these dwelling houses do not comply with the building code requirements especially in the provision of ramps whether at the time of erection of those houses or thereafter. In most cases, parents and caregivers of children with disabilities are left to fend for themselves in the provision of access to their rented apartments in buildings covered by the Code. This seems to enjoy the backing of government since landlords are authorised by statute to grant permission to persons with disabilities to provide their own

\footnotetext{
${ }^{1}$ National Building Code 2006, Section 4.5

2 DPDPA, Section 21

${ }^{3}$ National Policy on Education (2013) $6^{\text {th }}$ Ed, Section 7 Paragraphs 119 (a), 122

42003 Section 15

52004 Section 2

${ }^{6}$ Section 4.8 , Section 4.8.1

${ }^{7}$ Section 4.8 .2

${ }^{8}$ Section 4.8 .3

${ }^{9}$ National Building Code 2006 Section 4.9
} 
facilities to access rented apartments and to remove them at the determination of their tenancy contrary to law. ${ }^{1}$

It is submitted that the provisions of the building code makes it mandatory that approval shall first be sought and obtained before the houses are built to the specifications delineated and a prospective tenant has no input into the design and construction of the building. Government can no longer continue to play the ostrich with the right of children with disabilities and their families to access housing developments owned by either government or individuals. It is submitted that this provision ${ }^{2}$ of the Lagos State Special Peoples' Law is clearly inconsistent with the DPDPA and the National Building Code which are Federal Laws and therefore the LASSPEL is void to the extent of its inconsistency. It is therefore left to be seen how the DPDPA will address the wide chasm in this area during the transitory period, be it in the popular single room "face-me-I-face-you" buildings in high density sections of the urban centres, or the sprawling high rise buildings in major state capitals, or the 5-storey buildings in and around places like Onitsha, Aba, etc. with five-floor staircases, dysfunctional lifts and no ramps. The immediate assumption is that families with children with disabilities are not welcome in such residential structures since the difficulty in taking their children to the rented apartments is an instant frustration and manifest discrimination.

\section{Convention on the Rights of Persons with Disabilities (CRPD)}

The CRPD provides that to "enable persons with disabilities to live independently and participate fully in all aspects of life, States Parties shall take appropriate measures to ensure to persons with disabilities access, on an equal basis with others, to the physical environment, to transportation, to information and communications, including information and communications technologies and systems, and to other facilities and services open or provided to the public, both in urban and in rural areas. These measures, which shall include the identification and elimination of obstacles and barriers to accessibility, shall apply to, inter alia, buildings, roads, transportation and other indoor and outdoor facilities, including schools, housing, medical facilities and workplaces" ${ }^{3}$ It mandates States Parties to develop, promulgate and monitor the implementation of minimum standards and guidelines for the accessibility of facilities and services open or provided to the public. ${ }^{4}$

It is instructive that among the general obligations of States Parties to the CRPD are, among others, a respect for difference and acceptance of persons with disabilities as part of human diversity and humanity; equality of opportunity and accessibility. ${ }^{5}$ Unarguably, for children living with disabilities, having respect for difference and acceptance of persons with disabilities as part of human diversity and humanity is to demonstrate effort to ensure that they and their families have access and use of the environment, public buildings, facilities and infrastructures without discrimination and stigmatisation. This is buttressed by the emphasis that has been placed on the subject by the DPDPA and what remains to be seen is the enforceability of the law.

Yet, the DPDPA failed to capture the very essence of the dynamism in information technology and the vast need to deploy same to aid children with disabilities to relate with their environment. The CRPD clearly mandates that persons with disabilities should be exposed to information and communications, including information and communications technologies and systems, and to other facilities and services open or provided to the public, both in urban and in rural areas in a manner that is cognisant of their peculiar disabilities. A blind student, for instance, who boards a bus without an audio equipment to alert him of his arrival to school or home suffers discrimination on account of his disability and has been denied access to an equal use of the bus with his peers. A few states especially Lagos has great on-going transportation experiments, with provision in the Bus Rapid Transit (BRT) for persons with disabilities. However, all the buses observed so far have no ramps to enable persons with disabilities especially children have access to them resulting in their waiting for good Samaritans to bodily lift them into the buses even in peak hours. Where and when there is no such help, that child loses the equal opportunity of accessing his right to transportation, and the existing services intended for his use in the facility is shamefully occupied by non-disabled commuters who failed to assist her. Public buildings also do not host public signage in Braille for the visually impaired and unless they seek the assistance of others, they cannot get around public places without help which is a violation of their right to life, independent life and full participation in all aspects of society life.

The preamble to the CRPD recognises that children with disabilities should have full enjoyment of all human rights and fundamental freedoms on an equal basis with other children, and recalled obligations to that end undertaken by States Parties to the Convention on the Rights of the Child. ${ }^{6}$ It is submitted that in finalising designs

\footnotetext{
${ }^{1}$ Lagos State Special Peoples' Law Section 29(3) provides: A Landlord or Landlady shall allow a person living with disability lawfully occupying the property as a tenant to make such access related modifications to the building as would allow him or her access his or her apartment provided he or she shall remove such modifications before vacating the premises.

${ }^{2}$ Section 29(3)

${ }^{3}$ Article 9

${ }^{4}$ Article 9(2)

${ }^{5}$ Article 3

${ }^{6}$ Paragraph (r)
} 
to accommodate our cultural, climatic and other diversities which when completed will help commence construction to pilot the designs and test them for affordability and acceptance, as contemplated by the National Council on Lands, the "other diversities" must include, with utmost respect, environmental diversity, specifically dealing with accessibility in the lexicon of disabilities especially for children. The resolute enforcement and implementation of the DPDPA will demonstrate a reflection of government's desire to accommodate these other diversities and strengthen the regulation of buildings springing up at all levels in our national landscape. The description of equal opportunity in the circumstances of children with disabilities and their families can be extended to include the capacity of these children and their families to acquire the housing units in government schemes at cost. A reservation of a minimum of $10 \%$ of housing units built under the scheme for these children and their families at a discounted rate would be most encouraging and appropriate. This can be achieved under the endorsement of the adoption of Rent-to-Own product by all tiers of government to improve housing Inclusion, growth and economic prosperity.

In an unusual departure from existing Conventions, the United Nations for the first time expressly took cognisance of and made provision for the protection of children and women rights under the CRPD. The CRPD provides that States Parties shall take all necessary measures to ensure the full enjoyment by children with disabilities of all human rights and fundamental freedoms on an equal basis with other children. ${ }^{1}$ There is no corresponding provision on the right of a child with disability under the DPDPA. The provision dealing with liberty in the DPDPA ${ }^{2}$ is grossly inadequate, narrow and restrictive to contextualise the enjoyment of all human rights and fundamental freedoms on an equal basis with other children. In the same way, the provisions of the law on education and health would appear sparse in comparison to the expansive provisions of the CRPD to which Nigeria is a signatory. Accessibility is a function of acceptance and dissipation of discrimination. Therefore, buildings erected without regard to access for children with disabilities in both public and private developments fall short of the law and are not acceptable for any purpose.

\section{THE LEGAL IMPLICATIONS OF THE DPDPA}

Everyone has the right to live in a natural environment. ${ }^{3}$ The 1999 Constitution guarantees the right to freedom from discrimination to children with disabilities where such discrimination is on account of the circumstances of their birth. ${ }^{4}$ The implication is that the right to live in or access the environment is a human right linked to the right to life and this right is protected by law for every citizen including persons with disability especially children. As one author puts it, if you are a child with special needs, you have the right to be adequately provided for, in a way that makes you useful to yourself and your community. ${ }^{5}$ This reasoning accords with Section 16 of the Child's Right Act which guarantees the right of the child in need of special protection appropriate to his "physical, social, economic, emotional and mental needs and under conditions which ensure his dignity, promote his self reliance and active participation in the community." It is generally believed that the most daunting task to protecting the right of access to children with disability and persons with disability generally is the enforcement or application of the law. Clearly, the provisions of the DPDPA have been couched to ensure that there are remedies for any violations or breach of the law in consonance with the Latin maxim, ubi jus, ubi remedium, where a right exists, there is a remedy. In other words, it is intended by the law that legal consequences will follow, in some cases, for acts of omission ${ }^{6}$ and in others for acts of commission ${ }^{7}$.

The first task is to ensure that cases of discrimination, abuse, neglect or breach are brought to court for appropriate sanction and then, secondly, to ensure that when the cases get to court, the court itself is adequately equipped to give a robust interpretation of the law guided not just by the DPDPA but with reference to the Constitution and other regional and international instruments to which Nigeria is a signatory. As one legal writer puts it, "the availability of domestic judicial remedies for human rights violations is significant in two respects. First, human rights violations occur within a state principally in relations between a government and its own citizens. Second, it is essential and axiomatic that states remain primarily responsible in international law for enforcing the protection of human rights within their jurisdictions."

The Constitution provides that the social objectives of the State, that is, the Federal Republic of Nigeria, shall include the establishment of a social order founded on ideals of Freedom, Equality and Justice. ${ }^{9}$ Accordingly,

\footnotetext{
${ }^{1}$ Article $7(1)$

2 Section 19

${ }^{3}$ J. Verschuuren: The Constitutional Right to the Environment in the Netherlands, Revue juridique l'Environment/ Annee 1994/ 4 / 339 - 347 accessed online at https://www.persee.fr/doc/rjenv 039702991994 num 1943103 on 03/04/2019

${ }^{4}$ Section $42(2)$

${ }^{5}$ A. Tam-George: Children's Rights: A Handbook for Children and Young Persons, Abiye Tam-George \& Co. 2012

${ }^{6}$ Sections $8(2), 12(3),(4)$ and (5)

${ }^{7}$ Sections $1(2), 7(3)$

${ }^{8}$ J.A. Dada: Judicial Remedies for Human Rights Violations in Nigeria: A Critical Appraisal, Journal of Law, Policy and Globalisation, www.iiste.org, ISSN 2224 - 3259 (online) Vol. 10, 2013

${ }^{9}$ Section $17(1)$
} 
every citizen shall have equal rights, obligations and opportunities before the law ${ }^{1}$ and the independence, impartiality and integrity of courts of law and easy accessibility thereto shall be secured and maintained. ${ }^{2}$ The $^{2}$ Constitution further provides that the State shall ensure that there are adequate facilities for leisure and for social, religious and cultural life. ${ }^{3}$ The State is also mandated to protect and improve the environment and safeguard the water, air and land, forest and wild life of Nigeria. ${ }^{4}$ Although these provisions are described as Fundamental Objectives and Directive Principles of State Policy under Chapter II of the Constitution, it is common ground that they crystallize into rights upon the enactment of an Act of the National Assembly made pursuant to the powers of the legislature. ${ }^{5}$ It has been held that any of the principles of the Chapter is justiciable upon the enactment of a law of the National Assembly on any of the objectives. ${ }^{6}$

\section{The Role of the Judiciary}

The 1999 Constitution of the Federal Republic of Nigeria empowers the High Courts of the States and the Federal Capital Territory with original jurisdiction to hear and determine applications for the enforcement of fundamental rights guaranteed by the Constitution ${ }^{7}$ and to make such orders, issue such writs and give such directions as it may consider appropriate for the purpose of enforcing or securing the right to which the applicant may be entitled. ${ }^{8}$ We have contended and it is indeed fairly well settled that the rights contained in statutes enacted by the National Assembly have the same force as fundamental rights established by the Constitution. Thus, where the law clothes the courts with jurisdiction to enforce the provisions of the Constitution, it is presumed that it, mutatis mutandis, extends to the enforcement of the provision of all other statutes enacted by the National Assembly. The Constitution also provides that the rules for the practice and procedure of the courts for the enforcement of fundamental rights shall be made by the Chief Justice of Nigeria. ${ }^{9}$

In furtherance and in pursuance of the powers granted to him, the Chief Justice of Nigeria made the Fundamental Rights (Enforcement Procedure Rules) 2009 under Chapter IV of the Constitution. ${ }^{10}$ By the Rules, the appropriate Court to interpret the provisions of the fundamental rights guaranteed by the Constitution and statutes of the legislature, regional and international instruments and other bill of rights is the High Court including the Federal High Court, the High Court of a State and the High Court of the Federal Capital Territory. ${ }^{11}$ Among the overriding objectives for making the Rules is the expansive and purposeful interpretation and application of the Constitution, municipal, regional and international bill of rights with a view to advancing and realising the rights and freedoms contained in them and affording the protections intended by them. ${ }^{12}$ These include, among others, the 1999 Constitution, the African Charter on Human and Peoples' Rights, other instruments and protocols in the African Region human rights system, the Universal Declaration of Human Rights and other instruments and protocols in the United Nations human rights system. Among them are the Convention on the Rights of the Child, the Child Rights Act, African Charter on the Welfare of Women and Children and the Convention on the Rights of Persons with Disabilities.

\section{Abolition of Locus Standi in Human Rights Enforcement}

The general principle of law as adopted by the Supreme Court in Olawoyin Vs A.G, Northern Region ${ }^{13}$ is that only a person interested in the outcome of a cause can validly approach the Court to make a declaration on his behalf. ${ }^{14}$ In this sense, only a person whose rights have been affected by a statute may challenge its constitutional validity and that person's right must be directly or immediately threatened. ${ }^{15}$ The Supreme Court cited the decision of the Supreme Court of the United States of America in the case of Massachusetts V Mellon ${ }^{16}$ where it was held that "the party who invokes the power must be able to show that the statute is invalid but that he has sustained, or is immediately in danger of sustaining some direct injury as the result of its enforcement and not merely that he suffers in some indefinite way in common with people generally". The position would be the same as in taking

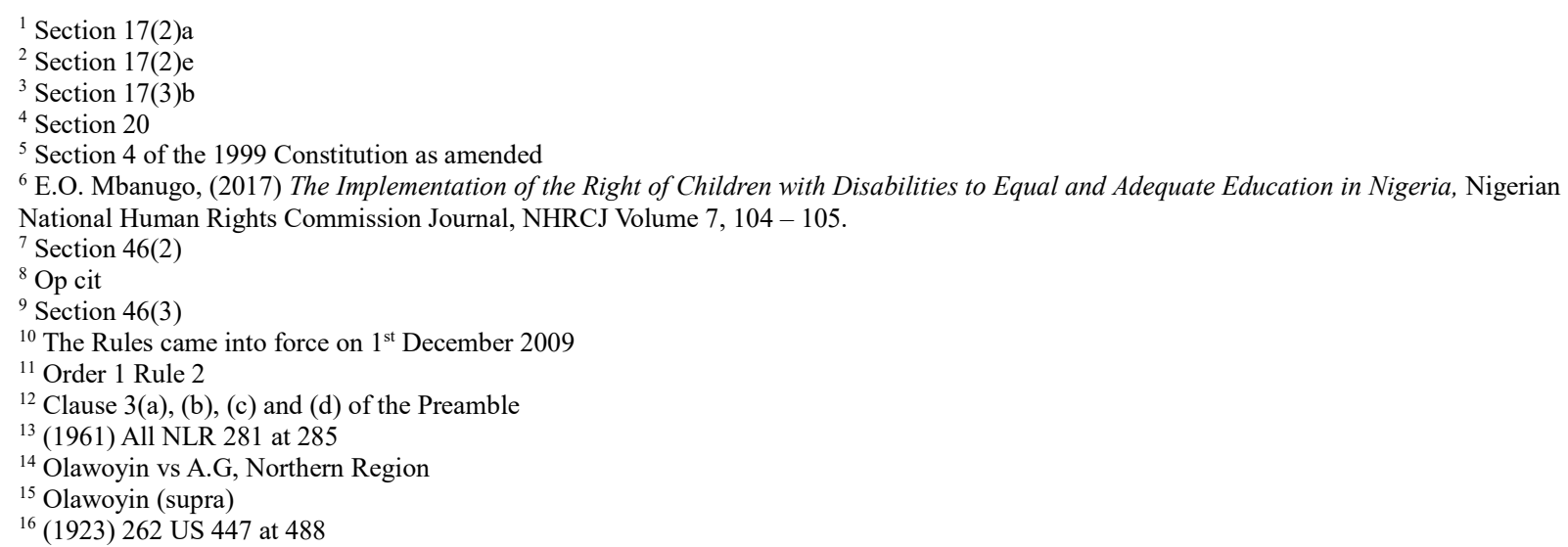


benefit of the provision of the statute where the party seeks to rely on it to enforce his right. The implication of this would have been that only persons with disabilities would have capacity to bring a cause or matter before the courts and this would have great injustice against children with disabilities. But this would appear to have been overruled by the mandatory provisions of the Constitution and the Fundamental Rights Enforcement Rules.

This is because the Fundamental Rights Rules has expanded the latitude of persons with interest who may bring an application to enforce such right to include among others, any one acting on behalf of another person, in the interest of a group or class of persons and in the public interest. ${ }^{1}$ Consequently, Olawoyin (supra) and cases decided prior to the 1999 Constitution and the Fundamental Rights Enforcement Rules on locus standi do not appropriately represent the current state of the law in Nigeria today. The Court is mandated to encourage and welcome public interest litigations in the human rights field and no human rights case may be dismissed or struck out for want of locus standi and in particular, human rights activists, advocates or groups as well as nongovernmental organisations, may institute human rights application on behalf of any potential applicant. ${ }^{2}$ The judiciary is therefore enabled by law to ensure a robust and vibrant enforcement of human rights instruments in Nigeria especially the DPDPA. In the words of one scholar, "judicial remedies are multifarious and multidimensional, and it is only the courts which are imbued with the jurisdictional competence to award them. The implication therefore is that victims of human rights violations have a wide range of remedies to choose from and are therefore not circumscribed by the problem of their inadequacy or unsuitability." 3 In a lot of ways, the interpretation of the Rules and the Constitutional rights will require judicial activism and uncommon courage to depart from rigid rules of interpretation of procedure and shun technicality. The Supreme Court of Nigeria is presently blazing the trail with landmark decisions in the case of Ukeje V Ukeje ${ }^{4}$ where the Supreme Court boldly and in so few words struck down the age-long Igbo peoples of Nigeria tradition which discriminated against the female child in inheritance of her deceased father's property.

By the same token, parents, caregivers and interest groups have the locus standi to engage the courts in pursuit of the enforcement of the right of access to the environment of children with disabilities in Nigeria. No doubt, access to the courts is a key factor in seeking to enforce the rights conferred by the DPDPA, much as it will be most desirable that issues arising at any time from those provisions will be amicably settled as between the victim and the government or individual party and even by administrative action. At any rate, it will be most deserving and welcome to see lawyers take up causes to encourage children with disabilities and their families seek redress for the violation of their right to access the environment in the same pro bono way as they do for criminal and other human rights causes.

This is because it is crucial to secure relief from an infringement or violation of the right to access the environment and other human rights accruable to children with disability including the right to education, health and social integration. Presently, the rate of violation, without statistics could be befuddling with regard to the scandalous rate of breach of the provision of ramps in public buildings including churches, mosques, market places, school buildings and residential accommodations. Except interest groups take up representative actions on behalf of traumatised and over $90 \%$ pauperised children and families of children living with disabilities, the rhetoric about the prohibition of discrimination against persons with disabilities especially children will remain what it is rhetoric.

\section{CONCLUSION}

The effective implementation and enforcement of Chapter II of the Discrimination against Persons with Disabilities (Prohibition) Act 2018 lies in the grit and determination of the executive arm of government to lead in the provision of adequate and appropriate facilities for access to the environment and compelling other institutions to ensure safe access to public buildings and places for children with disabilities. It lies in the deployment of adequate mechanism in the oversight function of the legislative house to ensure compliance with the law. It also lies in a disciplined and robust judiciary primed to respond to internationally acceptable democratic ethos in the enforcement of human rights in accordance with the Constitution, the Rules, domestic and international instruments and global best practices and principles. As the Supreme Court of Nigeria said in the case of Medical and Dental Practitioners Disciplinary Tribunal V Dr. John E.N. Okonkwo "the courts are the institutions society has agreed to invest with the responsibility of balancing conflicting interests in a way as to ensure the fullness of liberty without destroying the existence and stability of society itself."

There seem to be, currently, a tepid approach to the enforcement and implementation of the policy on ensuring

\footnotetext{
${ }^{1}$ Preamble Clause 3(e)

2 Op cit

${ }^{3}$ J.A. Dada: Judicial Remedies for Human Rights Violations in Nigeria: A Critical Appraisal, Journal of Law, Policy and Globalisation, ISSN 2224 - 3259 (Online) Volume 102013

${ }^{4}(2014) 4$ S.C. (Pt. I) 1 at $28-29$

${ }^{5}$ (2001) 3S.C. 76 at 105
} 
accessibility to public places in state jurisdictions with existing law ${ }^{1}$ on discrimination against persons with disabilities including creating ramps in existing public buildings, providing lifts in public vehicles etc. Notwithstanding the lapse of five years compliance window in Lagos State Special Peoples' Law, there is a chasm between the enactment of the law and its enforcement. Although many government buildings and public places are striving to comply, the same cannot be said of religious houses, schools, market places, residential accommodations, restaurants, shopping malls and plazas. Effort should be intensified to enforce the provisions of the DPDPA in this direction as children with disabilities are constantly denied access even to school buildings, places of worship, transportation, eateries, etc. No doubt, a denial of access to these public places is a denial of their human rights and fundamental freedoms on an equal basis with other children.

It will be most profitable to the world of children with disability and policy implementation and enforcement for government to ensure a diligent implementation and application of Resolution 4(xxx) of the communiqué of the National Council on Lands, Housing and Urban Development in tandem with best practices in furtherance of the DPDPA. This is because even in places where facilities and services have been provided for children with disabilities, accessing those facilities and services are most problematic. All stakeholders must step forward with adroit recommendations for the enforcement and implementation of the DPDPA. Judges and lawyers must engage a robust and proactive approach towards the interpretation of the Act. Civil Society, parents, caregivers, guardians and non-governmental organisations should engage governments at all levels to give fillip to the realisation of the objectives of the DPDPA. The legislator and policy makers must come to terms with current global trends relating to the disability world especially relating to children and make further allowances for the emergence of a less traumatised and intimidated demographic in our polity.

Although the Courts must interpret our laws in accordance with our statutes, where the provisions are overly restrictive or there is a dearth of the law, a challenge that will necessarily arise in interpreting the DPDPA, the courts must be sufficiently courageous to give a bold and wider interpretation of the Constitution and the law in compliance with international best practices as an indication of Nigeria's commitment to universal principles and international conventions and norms adopted by the country. In the Medical \& Dental Practitioners Disciplinary Tribunal Case (supra), the Supreme Court of Nigeria admitted the dearth of authorities in the area of law considered in that case ${ }^{2}$ and had recourse to the sufficiency of the provisions of the Constitution of the Federal Republic of Nigeria and foreign authorities in coming to its decision. The provisions of the DPDPA derive their live from Section 42 of the 1999 Constitution and it is appropriate to contend that it is sufficient law upon which the court will perform its role "to ensure the fullness of liberty when there is no danger to public interest." ${ }^{3}$ Indeed, in the most recent case of Tega Esabunor \& Anor. V Dr. Tunde Faweya \& Ors. ${ }^{4}$, the Supreme Court, relying on its decision in Medical \& Dental Practitioners Disciplinary Tribunal v Okonkwo (supra), held that the essence of law is to preserve life and property and create environment for human beings to live a contented and dignified life, and the courts should step in where a competent parent or one in loco parentis fails to take a decision which will be in the best interest of the child. The Court went further and said:

"It is instructive to note that the law exists primarily to protect life and preserve the fundamental right of its citizens inclusive of infants. The law would not override the decision of a competent mature adult who refuses medical treatment that may prolong his life but would readily intervene in the case of a child who lacks the competence to make decisions for himself. See the case of Medical and Dental Practitioners Disciplinary Tribunal V Dr. John Emewulu Nicholas Okonkwo\{2001) 7 NWLR (Pt. 711) 206. Note also that the Child's Right Act, LFN 2003 is replete with judicial powers to ascertain the survival and total well-being of the child. ........ Section 59(a) provides that:

"Where it appears to the Court in proceedings in which a question arises as to the welfare of a child, that it may be appropriate for a care supervision order to be made with respect to that child, the court may direct the appropriate authority to undertake than investigation of the child's circumstances."

It is beyond argument that the above sections of the Child's Right Act confer enormous powers on the courts to secure the right of children especially those requiring special protection such as children with disabilities. The purpose of this paper will be achieved if our courts will robustly interpret the DPDPA to respond to the essence of law to give children living with disabilities a sense of contentment and dignity in their environment. It will also be achieved when sufficient awareness is created compelling school curricula to include lessons on disability education and access to the environment for disability community; and law students mandatorily elect a study in disability jurisprudence and policy as a way of forming a vanguard of future advocates for children with disabilities.

\footnotetext{
${ }^{1}$ Since the enactment of the Lagos State Special Peoples Law, a period of more than five years has lapsed and there are yet an alarming proportion of violation of the law in the refusal to provide ramps, lifts and visual and aids in public buildings and other physical structures. ${ }^{2}$ Op cit at page 104 line 6

${ }^{3}$ Medical \& Dental Practitioners Disciplinary Tribunal v Okonkwo (supra) at page 105 line 11

${ }^{4}$ LER(2019) SC. 97/2009.
} 


\section{REFERENCES}

1. Dada, J.A., (2013), “Judicial Remedies for Human Rights Violations in Nigeria: A Critical Appraisal”, Journal of Law, Policy and Globalisation, www.iiste.org, ISSN2224 - 3240 (Paper) ISSN 2224 - 3259 (Online) Vol. 10, 2013Garner, B., (2009) Black's Law Dictionary, Thomson Reuters, $9^{\text {th }}$ Edition

2. Child's Right Act 32003

3. Constitution of the Federal Republic of Nigeria 1999.

4. Mbanugo E.O., (2017), The Implementation of the Right of Children with Disabilities to Equal and Adequate Education in Nigeria. Nigerian National Human Rights Commission Journal NHRCJ Vol. 7, 77 - 107.

5. Medical and Dental Practitioners Disciplinary Tribunal V Dr. John Emewulu Nicholas Okonkwo \{2001) 7 NWLR (Pt. 711) 206.

6. Prohibition: Unintended Consequences, What was bad about Prohibition, www.pbs.org $>$ kenburns accessed at 4.45p.m on 09/04/2019

7. Tega Esabunor \& Anor. V Dr. Tunde Faweya \& Ors. LER(2019) SC. 97/2009

8. Universal Declaration of Human Rights, United Nations 1948.

9. United Nations Committee on the Rights of the Child, $43^{\text {rd }}$ Session, General Comment No. 9, The Rights of Children with Disabilities

10. Verschuuren, J.: The Constitutional Right to the Environment in the Netherlands, Revue juridique l'Environment/ Annee 1994/ 4 / 339 - 347 accessed online at https://www.persee.fr/doc/rjenv_0397_0299_1994_num_19_4_3103 on 03/04/2019

11. World Bank Group, Disability Inclusion, accessed online $\overline{\text { at }} \overline{\mathrm{h}} \mathrm{ttps}: / /$ www.worldbank.org/en/topic/disability April 12, 2019.

Emenike Olisa Mbanugo is a legal practitioner based in Lagos, Nigeria, with over 28 years experience in litigation, advocacy and arbitration. He obtained his Bachelor of Laws from the Anambra State University of Technology (now Nnamdi Azikiwe University) Awka, Nigeria in 1989 and a Master of Laws degree in Legislative Drafting from Nigerian Institute of Advanced Legal Studies, Lagos, Nigeria in 2013. His Masters Degree thesis was titled "Regulating the Emissions from Commercial Aircraft in Nigeria". He is a prospective doctoral degree student. He was admitted to the Nigerian Bar in 1990. He has made several presentations on rights of children with disabilities, environmental law and policy and the peculiarity of physical and environmental rights. Over the past few years, his research and presentations at conferences and seminars has focused on child rights especially children living with disabilities, their families and caregivers. He co-founded Chukwuebuka Exceptional Children Foundation. 